\title{
United Nations Update
}

\section{Global Violence \& Health}

\section{Flora K. Bloom and Kathleen Schmalz}

The World Health Organization (WHO) released its first World Report on Violence and Health and the related year long Global Campaign for Violence Prevention in Geneva, 2002 - 2003. We welcome this Report because it makes a contribution to our understanding of violence and the impact it has on the health of all of us. And in doing so, it informs us of the many different forms of violence that can be prevented and countered by governments, communities, and individuals.

Mentioned in the WHO Report is the violence perpetrated on girls as they are at highest risk of infanticide, sexual abuse, neglect and being forced into prostitution, while boys are more often the victims of beatings and physical punishment. In addition, the Report recognizes the problems of child abuse and neglect by parents that not only leads to death but to physical, sexual and psychological nonfatal abuse. In the WGG Fact Sheets, information is provided on health and violence issues with recommendations to stop violence against girls that supports WHO's goals.

The goals of the WHO campaign is not only meant to raise awareness about violence as a public health issue but to emphasize prevention and offer opportunities for collaboration and exchange of information on violence prevention. WHO is contacting governments, institutions, NGOs and community organizations to encourage them to participate in the Global Campaign for Violence Prevention.

The Report that is complemented by the campaign presents a set of recommendations for action at the local, national, and international levels. If your organization is actively involved in research, advocacy or prevention related to violence at an international level, WHO would be pleased to add your organization to a list of violence-related organizations on their website.

Table 1

Web Sites

\begin{tabular}{|c|l|}
\hline \multicolumn{1}{|c|}{ Web Site } & Web Address \\
\hline & \\
\hline $\begin{array}{c}\text { United Nations Children's Fund (UNICEF) } \\
\text { For UNICEF issues of violence, abuse, neglect } \\
\text { and exploitation threatening children, visit } \\
\text { UNICEF's Priorities for Children 2002- 2005. }\end{array}$ & http://www.unicef.org \\
\hline $\begin{array}{l}\text { WHO Injuries \& Violence Prevention } \\
\text { Under "Injury Prevention Collaborative } \\
\text { Activities". }\end{array}$ & http://www.who.int/violence injury prevention/ \\
\hline $\begin{array}{l}\text { Working Groups on Girls (WGG) } \\
\text { Under Girls Situations-- WGG Fact sheets on } \\
\begin{array}{l}\text { Girl Child Health Issues, Girl Child and } \\
\text { HIV/AIDS, Violence Against Girls and others. }\end{array}\end{array}$ \\
\hline
\end{tabular}




\title{
References
}

Friedman, S.A. (n.d.). Keeping promises to girls: Following up on the UN special session for children. [brochure]. NGO Committee on UNICEF/Working Groups on Girls.

United Nations Children's Fund. (2002). UNICEF's priorities for children 2002-2005. New York: Author. World Health Organization. (2002). World report on violence and health: Summary. Geneva, Switzerland: Author.

\author{
Author Information \\ Flora K. Bloom, Ed.D., CHES \\ Kathleen Schmalz, Ed.D., RN, CHES \\ NGO Representatives to the United Nations \\ American Association for Health Education (AAHE) \\ International Union for Health Promotion and Education (IUHPE) \\ Society for Public Health Education (SOPHE)
}

